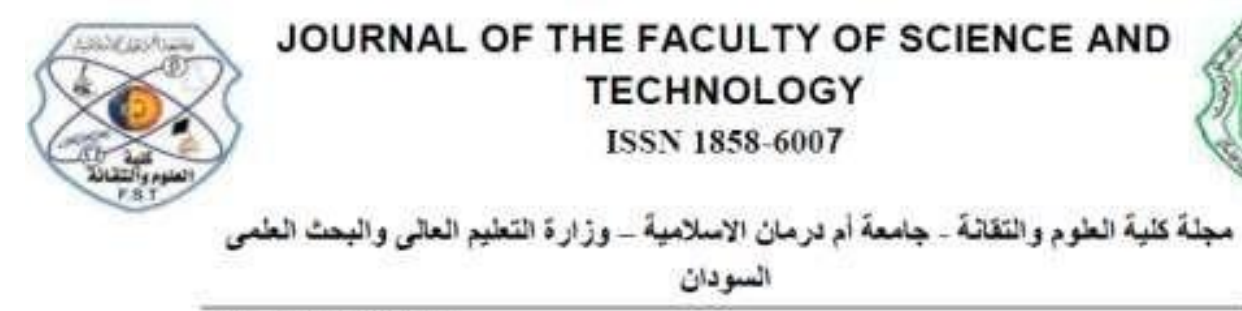

Research article

\title{
The effect of the addition of limestone from Khor Eit on soil stabilization of Omdurman.
}

\author{
Amna Mubarak Mohamed Elhag
}

Geological Research Authority of the Sudan, Email:engamna@hotmail.com

\begin{abstract}
The present investigation considered the damages arising from the expansive clay type in the presence of water in Omdurman -Sudan.

Geographic Information System (GIS), and Remote Sensing techniques were used to map the geotechnical parameters and accurately locate the problematic clay zones.

Soil samples recovered from the Bore Holes and Trial Pits in Al muhandessen, Elbustan, Alarda, Bit Almal and Almulazmeen, during the field work carried out in August 2018 were studied using standard Geotechnical Laboratory methods. The liquid limit varies between $50 \%$ and $65 \%$.

The samples locations were determined using the Global Positioning System (GPS). The thematic mapper 2000Tm was used for mapping the soil properties in Digital format using ERDAS Imaging 8.5 integrated with other software such as Arc Map. Modeling of the problematic soil was carried out also.

The results of the geotechnical data show that montomorillonite and Illite are the dominant high expansive clay type with thickness ranging from one to three meters.

The limestone collected from Khor Eit North of Port Sudan, was studied chemically and Calcined at $900^{\circ} \mathrm{C}$ and slaked to get lime. $(10-20 \%)$ of the lime was added to the sample soil with compaction, results in enhancement of the soil properties, reduction of the plasticity index, reduction of clay activity and hence stabilization of the soil.
\end{abstract}

\section{Introduction:}

The republic of Sudan is located in the northeastern part of Africa. Khartoum combined with Khartoum North, and Omdurman constitutes the capital of the country. Omdurman is located west of the River Nile, and bounded by the Latitudes $15^{\circ} 32^{--} 15^{\circ} 52^{-} \mathrm{N}$, and Longitudes $32^{\circ} 22^{-}-32^{\circ} 32^{-}$E. The Study area is situated in the western part of Khartoum, the state Capital and the central part of Sudan (Fig 1.1) and covers an area of 680,184 square Kilometers.

The Geology of the area is mainly composed of Nubian sandstone underlined by the Basement 
complex. The Nubian Sandstone is overlained by the recent deposit which is mainly of Nile Silt, Sand dunes, gravel, sand and clay which covered the seasonal drainage (Al Mond, DC, 1967).

Work in the United States, South Africa, and France has established the benefits of lime stabilization of calcareous bases of road construction (Mielenz R. C, King M. E 1955).

The problem of the cracks, shown at the excavated trial pit which drilled near the cracked buildings (Fig 1.2.1), and the damage of asphaltic roads, encouraged us to investigate the area and to seek for suitable solutions.

The problematic soil present in the area is the Recent Deposits (agricultural soil). The agricultural soil classification is based on laboratory measurement of the shrink - swell clay.

The dominant types of clay mineral present in the area are smectite or Illite groups together with kaolin.

The presence or sources of water that are mobile enough to reach the expansive soil in the investigated area and the amount of the discharged water originates from the domestic use, results in the damage and expansion of the clay.

The addition of the lime to the expansive clay of Omdurman improve the soil properties and stabilize the soil due to the decrease of the plasticity index. The Remedial measurement of the expansive clay using limestone from Khor Eit North of Port Sudan resulting in stability of the soil and enhance the plasticity index by reducing the liquid limit of the soil.

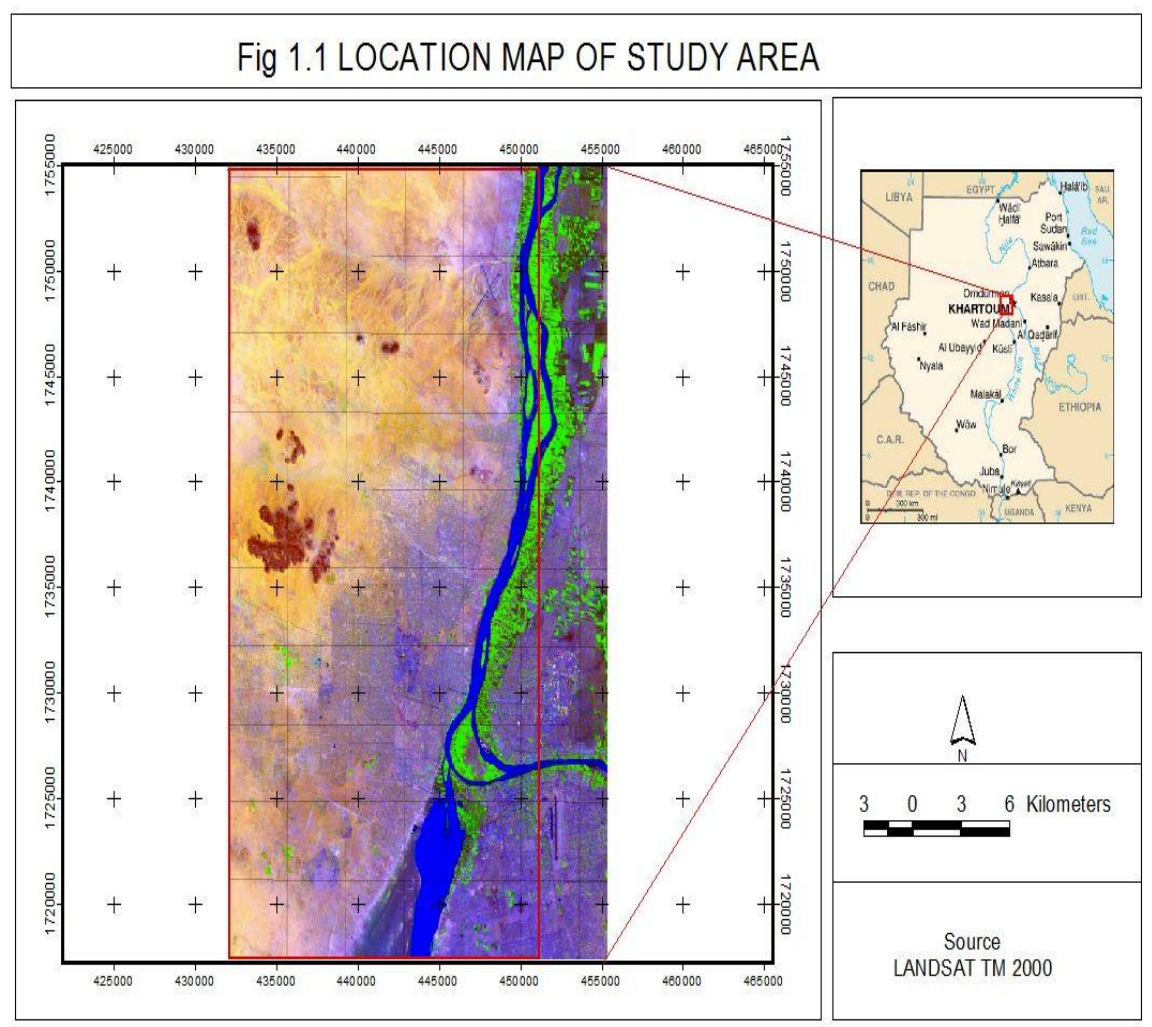



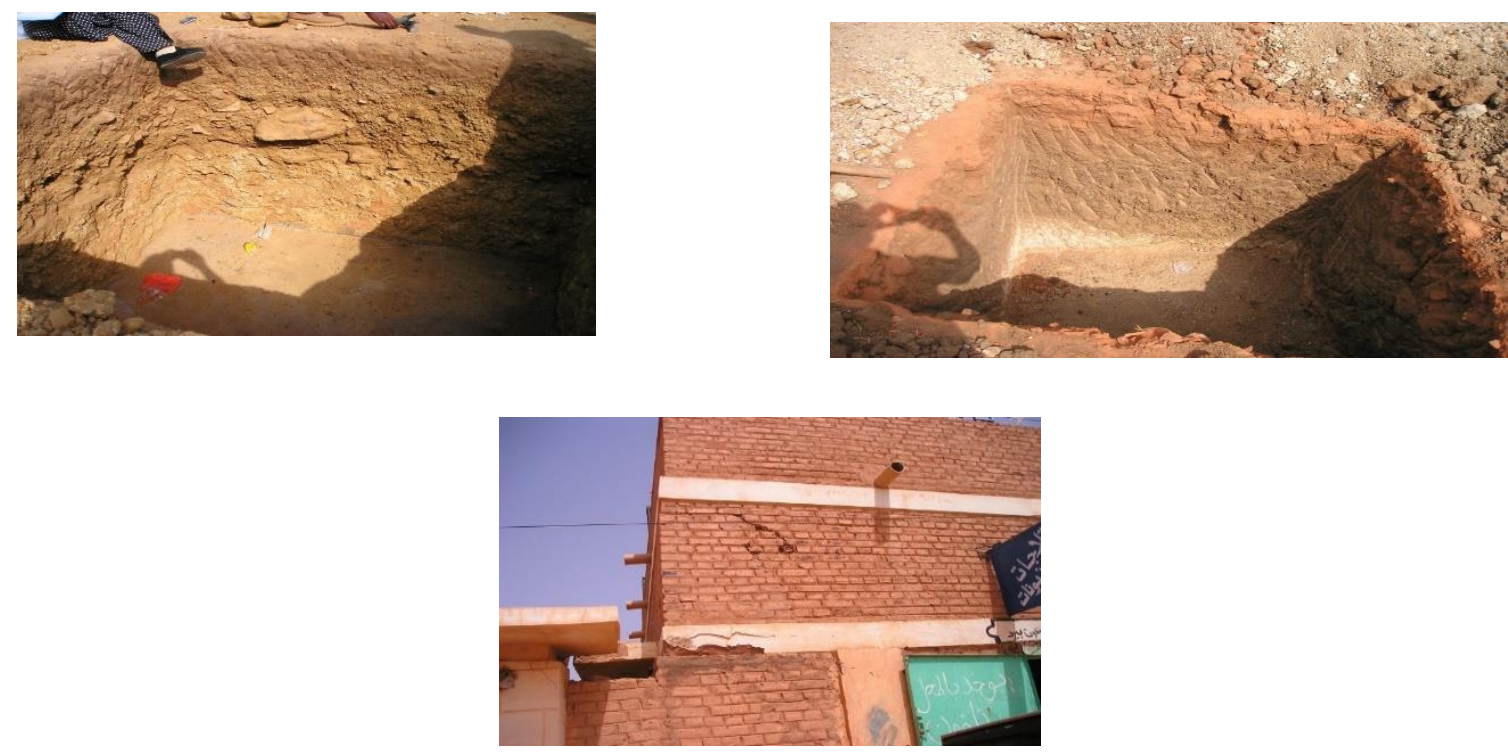

Fig (1.2.1) the trial pit excavated near the cracks building where the closely spaced fissured clay detected

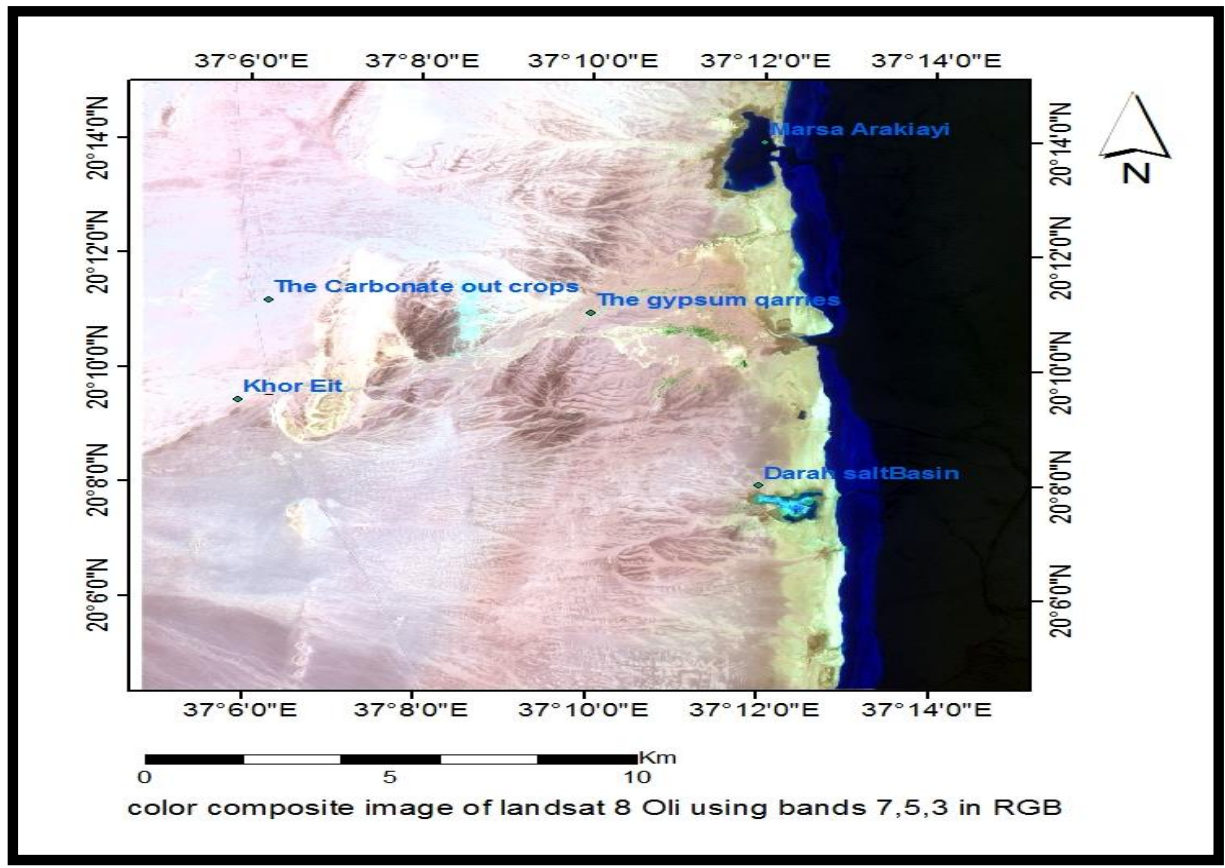

Fig (1.2.2) the location of the limestone samples collected for from Khor Eit North of Port Suda

\section{Objectives of the study:-}

The main objective is the Remedial measurement of the expansive clay using limestone from Khor Eit North of Port Sudan by the addition of Calcined lime at different percentage (20\%, and 10\%).

Calcination of Khor Eit limestone to attain the high pure limestone of high calcium oxide percentage.

\section{Materials and Methods:}

Field data Acquisitions: 
Landsat Image processing.

The field data collection and acquisition using Geographic positioning system (GPS) for soil samples collections and Limestones collections were performed.

2- Subsurface Geotechnical mapping of the data obtained from field sampling of the disturbed samples which collected from the drilled trial pits.

3- Generation of Geotechnical Map of Soil and Rock 1:50000

, and modeling the affected area using GIS, Remote sensing and GPS techniques.

Calcination of limestone collected from Khor Eit and added to the expansive clay in different percentage to get the minimum percentage for soil stabilization. The plasticity index determined to achieve the goal required for soil enhancement and stabilization.

Decomposition of limestone test and Calcination of Lime at furnace by heating at $800-900^{\circ} \mathrm{C}$ which called calcination of limestone, the selected samples from Arus which have high pure carbonates where the Calcium oxide ranges $45-50 \%$ and the $\mathrm{CO} 2$ between $40-45 \%$.followed by slaking of the quick lime by the addition of water and converted to the $(\mathrm{Ca}(\mathrm{OH}) 2)$ or lime.

Coralline Limestones at Arus contained $95-99 \%$ by weight of $\mathrm{CaO}$ which has enable it to be applied for quite a number of purposes

Tools used in the study:

ERDAS Imagine 8.5 used, for digitizing, classifying image, and calculations of the area of each class (graph 2). In addition to the Arc GIS for delineations of soil units (fig5.1).

Microsoft Excel-to plot the graphs.

Grain size distribution determined by Hydrometer method using dispersing stirrer by sodium MetaHesta-phosphate.

Furnace for decomposition of limestone to calcium oxide and carbon dioxide at 800-900.

The chemical analysis of limestone determined by using x-ray fluoresces.

Geotechnical site investigation was carried out with the objective of minimizing the risk of the building located on the problematic soil such as expansive clay. The aim of the study to acquire knowledge of the site by obtaining sets of geotechnical data of collected samples from Omdurman. Then addition of the limestone the fresh one which collected from khor Eit north of port Sudan and, that was studied chemically to determine the percentage of the Calcium oxide and calcined to get the lime product after hydration and slaking which could be added to enhance the plasticity index of the soil or stabilizing the soil. 
The objective main of this study is to investigate the soil properties.

1. Map the potential area of the active clay causing collapse of the buildings. , and

3. Generate and produce a 3-dimensional geologic model of the soil layers using remote sensing, Land Satellite image2000, and Geographic positioning system, ERDAS Imaging software programmes.

\section{Results of image processing and data entry:}

Data entry is the land sat imagery 2000 ,resolution of 30 meters, which processed and enhanced .the goal of enhancement is to improve the visual interpretability of the image to by increasing the apparent distinction between the feature in the scene, that amplifying the slight differences between those features to make them readily observable then geometric correction for the image ,followed by unsupervised and supervised classification, and building of polygons then calculation of the land use and land covered in the studied area, the wadies, and rivers(graph No 2)

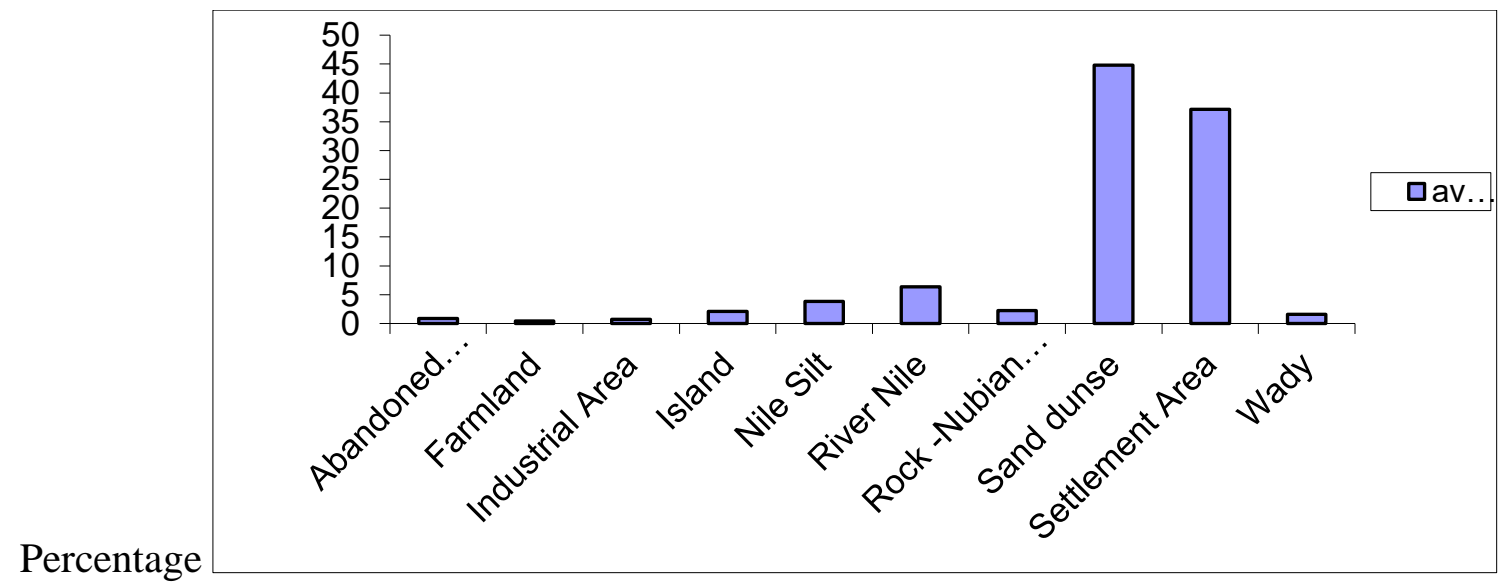

Graph (2) The Plot of Relative Proportion Percentage of Land use and Land cover Area.

The Basic Map of limestone used in the field data acquisition:

The preparation of the satellite Image is the work office of processing of the base map.

The studied area coverage by some satellite Images, which combined by adjacent images into mosaic, using ENVI 4.5 software spatial sub-setting was performed on the raw digital images that including band 1, 2, 3,4,5,7 and 8 in order to spatially resize the co-ordinates of the studied area.

\section{The stretching Contrast:}

The contrast was carried to produce amore interpretable images (Sabin, 2000).Image sharpening was used, to automatically merge the low-resolution multispectral band, with the high resolution gray scale band.

The input data of the land-satellite image was transformed, from RGB color system to IHS system, by Intensity -Hue -Saturation .Transformation (IHS) methods of processing. Moreover linear contrast stretching was applied to the intensity (brightness) of the image in order to improve the discriminating, and geocoded, and the locations of the collected samples attached to the Landsat using GPS and cable 
connection (fig 1.2.2).

\section{Field of soil investigation of Omdurman:}

The field trip was done to accurately survey a significant number of the affected area .More site investigations for geotechnical properties of the soil, to determine and test the observable cracks at the buildings were carried out, and trial pits were excavated for collecting data .The GPS was used for the data collection to determine the position. Moreover data observation and questionnaire for water resources were done.

\section{Field tests for limestone detection:}

The samples of Limestones collected from the field work and tested by the addition of hydrochloric acid, chemical property determination is also important in the assessment of Limestone Results of chemical analysis, decomposition, calcination and hydration of limestone:

Typical Oxides of the chemical analysis of limestone:

Limestone is $\mathrm{CaO}$ as major oxides an alumino silicates compound as accessories with SiO2, AL2O3 and, $\mathrm{K} 2 \mathrm{O}, \mathrm{Na} 2 \mathrm{O}$ in minor amounts, the oxide composition of limestone (table 3).The limestone from the central of Khor Eit and Arus deposit remains relatively of high percentage of $\mathrm{CaO}$. Chemical compositions of a number of limestone samples from various locations in the study area are shown in (Table 3.1 and $\mathrm{MgO}$ as main oxides).

Table (3.1) the chemical composition of limestone from Khor Eit North of Port Sudan

\begin{tabular}{|c|c|c|c|c|c|c|c|c|c|c|c|}
\hline $\begin{array}{c}\mathrm{C} \\
\mathrm{u}\end{array}$ & $\begin{array}{c}\mathrm{Ti} \\
\mathrm{O} 2\end{array}$ & $\mathrm{CaO}$ & $\mathrm{K} 2 \mathrm{O}$ & $\begin{array}{c}\mathrm{SO} \\
3\end{array}$ & $\begin{array}{c}\mathrm{P} 2 \mathrm{O} \\
5\end{array}$ & $\mathrm{SiO} 2$ & $\begin{array}{c}\mathrm{A} 2 \\
\mathrm{O} 3\end{array}$ & $\begin{array}{c}\mathrm{Mg} \\
\mathrm{O}\end{array}$ & $\mathrm{Na} 2 \mathrm{O}$ & $\mathrm{CO} 2$ & contents \\
\hline $\begin{array}{c}0 . \\
00\end{array}$ & $\begin{array}{c}0.0 \\
53\end{array}$ & $\begin{array}{c}45.67 \\
1\end{array}$ & $\begin{array}{c}0.01 \\
7\end{array}$ & $\begin{array}{c}0.3 \\
36\end{array}$ & $\begin{array}{c}0.14 \\
1\end{array}$ & 3.763 & 1.15 & 0.2 & 0.134 & 45.5 & $\begin{array}{c}\text { oxide } \\
\%\end{array}$ \\
\hline
\end{tabular}


Table (3.2) Classification of Limestone according to Mineralogical composition (Boynton1966 )

\begin{tabular}{|c|c|c|c|}
\hline Limestone in the study area & $\begin{array}{c}\text { MgCO3 } \\
\text { percentage }\end{array}$ & $\begin{array}{c}\text { Ca CO3 } \\
\text { percentage }\end{array}$ & $\begin{array}{c}\text { Type of } \\
\text { Limestone }\end{array}$ \\
\hline Arus\&Central Khor Eit & & $\begin{array}{c}95 \%- \\
100 \%\end{array}$ & $\begin{array}{c}\text { High } \\
\text { calcium }\end{array}$ \\
\hline K.Ei \& Abu imama & $5 \%-35 \%$ & & $\begin{array}{c}\text { Magnesiu } \\
\text { m } \\
\text { Limestone }\end{array}$ \\
\hline K.Eit,Tobanam\& Abu & $35 \%-46 \%$ & & $\begin{array}{c}\text { Dolomitic } \\
\text { Limestone }\end{array}$ \\
\hline
\end{tabular}

\section{The calcination of pure limestone at Arus:}

Coralline Limestones at Arus contained $95-99 \%$ by weight of $\mathrm{CaCO} 3$ which has enable it to be applied for quite a number of purposes. Equation (1) represents the decomposition process of limestone which is denoted by decomposition of $\mathrm{CaCO}$. Via thermal decomposition process which is known as calcination, $\mathrm{CaCO} 3$ can be converted into $\mathrm{CaO}$ which is used in industries and daily practice such as in waste water and sewage treatment, glass production, construction material

$$
\text { CaCO3 } \underset{\mathrm{T}\left(800-900^{\circ} \mathrm{C}\right)}{\longrightarrow} \mathrm{CaO}+\mathrm{CO} 2+\text { Heat... equation } 1
$$

Limestone which is denoted by decomposition of $\mathrm{CaCO} 3$. Via thermal decomposition process which is known as calcination, $\mathrm{CaCO} 3$ can be converted into $\mathrm{CaO}$

The analysis also indicates the presence of lime, $\mathrm{CaO}$, in the Calcined coralline Limestones range between $45 \%-35 \%$ lost on ignition. Thus, these findings suggest that thermal decomposition of coralline Limestones converts $\mathrm{CaCO} 3$ contained into $\mathrm{CaO}$.

\section{Slaking of Lime in accordance to physical properties of row materials:}

The calcium hydroxide crystals which are formed by slaking of heated white Limestones, the white Limestones have an amorphous appearance, and limes produced from have a microcrystalline structure. (plate5.3.1). on scanned electron micrographs, formed limes appear as a cluster of very fine particles having less than 1 micrometer diameter.

\section{Slaking of Lime in accordance to physical properties of row materials:}

The calcium hydroxide crystals which are formed by slaking of heated white Limestones glimes

Plate (5.3.1) Electron microscope images and the calcium oxide crystals produced have a microcrystalline structure. (plate.3.1). on scanned electron micrographs, limes appear 


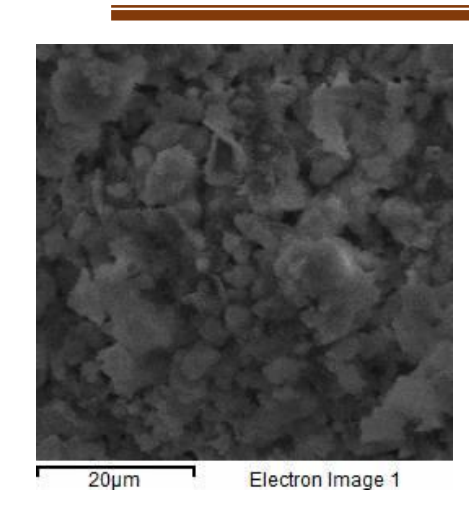

as a cluster of very fine particles having less than 1 micrometer diameter. The scanning electron analysis indicated that lime was composed of micritic calcite crystals connected with fibrous network

Results and discussion of the Geotechnical properties of the soil at the affected zone at Omdurman: Grain size analyses indicated clay - size $(<75 \mu)$ fraction of which represent 58 percent (for the closely spaced fissured as described from field work) and 36 percent (for the widely spaced fissured one) .The (> $(75 \mu)$ were Silt and Sand with few gravel.

Testing of fine grained materials, commonly exposed on the surface of the active part of the effected zone of the study area, indicate both clay rich materials, with high plasticity, and high potential.

The Atterberg limits test using the American standard testing method (ASTM D4318) determine the moisture contents at which the portion of the soil smaller than $2 \mathrm{~mm}$ grain size transition from a brittle solid to plastic which the liquid limit, and from a plastic solid to a viscous liquid. The results are called plastic limit and liquid limit respectively .The plasticity index is the difference between the liquid limit and plastic limit.

The results of the liquid limits revealed the clay is active and the index description as clay of high plasticity index.

Table 2.1 Classification system identifying potentially of soil by determination of clay activity after Holz and Gibbs(1993)

\begin{tabular}{|c|c|c|c|c|c|}
\hline $\begin{array}{l}\text { Result after the } \\
\text { addition of the } \\
20 \% \text { lime }\end{array}$ & $\begin{array}{l}\text { Resu } \\
\text { lts }\end{array}$ & $\begin{array}{l}\text { Locatio } \\
\mathrm{n}\end{array}$ & Range of Activity & Activity $\%$ & $\begin{array}{l}\text { Mineral } \\
\text { Type }\end{array}$ \\
\hline & & & $0.4-0.5$ & 0.25 & Muscovite \\
\hline & & & $0.5-0.75$ & 0.4 & Kaolinite \\
\hline & 0.75 & Elarada & $0.75-1.25$ & 0.9 & Illite \\
\hline 0.65 & 1.27 & $\begin{array}{l}\text { Alwaha } \\
\text { a }\end{array}$ & $>1.25$ & $>1.25$ & $\begin{array}{l}\text { Montmorillo } \\
\text { nite }\end{array}$ \\
\hline 0.75 & 2.2 & $\begin{array}{l}\text { El } \\
\text { Bustan }\end{array}$ & $>1.25$ & & $\begin{array}{l}\text { Montomorill } \\
\text { ient }\end{array}$ \\
\hline
\end{tabular}

Testing of clay and Classification system which is given in Table 2.1.In order to quantitatively 
characterize the expansive soils. As the main cause of damage to the structures built on expansive soil is due to the volume change behavior of such soils. The addition of the lime to the expansive clay of Omdurman enhance the soil properties and stabilize the soil hence decrease the plasticity index (Holmes S., and Wingate M., 1997).the addition of lime in different weight percentage of the expansive clay samples prepared for Atterberg limits test, which are ranges between 30\%, 20\% and 10\% respectively the results at table

Expansive soil, or the shrink-swell soil, that contain Aluminum and Silicon sheets and extremely are small which cause the expansion and held together by intra molecular forces. The expansion potential of the soil is determined by the percentage of clay and the type of clay in the soil (table 2.1 and 2.1.1) (Mielenz R.C., King M.E., 1955).

\section{The plasticity index of the soil at Omdurman:}

The plasticity index is the parameter obtained from the classification of the Atterberg limit from laboratory testing results using (ASTMD4318) method .comparison of plots of the two materials on Casgrands plasticity chart for the common clay minerals (table2.1) shows that the clay minerals near the zone of typical for montomorillonite.

The plasticity index(PI) of the materials of soil suggested clay of high plasticity .the clay activity is the result of the divitions of the plasticity index value by the percentage of clay at the sive analysis product (PI/clay percentage ) which revealed that the type of clay is very active or montomonorollite according to the (Holtz and Gibbs,1993) classification.

Table 3.2 the liquid limit testing results before and after the addition of lime

\begin{tabular}{|c|c|c|c|c|c|c|}
\hline $\begin{array}{c}\text { The } \\
\text { Liquid } \\
\text { limit } \\
\text { after } \\
\text { treatmen } \\
\mathrm{t} \\
10 \% \\
\text { lime }\end{array}$ & $\begin{array}{l}\text { The } \\
\text { Liquid } \\
\text { limit } \\
\text { after } \\
\text { treatmen } \\
\mathrm{t} \\
20 \% \\
\text { lime }\end{array}$ & $\begin{array}{l}\text { The } \\
\text { Liquid } \\
\text { limit } \\
\text { after } \\
\text { treatmen } \\
\text { t } 30 \% \\
\text { lime }\end{array}$ & $\begin{array}{c}\text { The } \\
\text { liquid } \\
\text { limit } \\
\text { before } \\
\text { treatment }\end{array}$ & $\begin{array}{c}\text { Potential } \\
\text { Swell }\end{array}$ & $\begin{array}{c}\text { Plastici } \\
\text { ty } \\
\text { index } \%\end{array}$ & $\begin{array}{c}\text { Liqui } \\
d \\
\text { Limit } \\
\%\end{array}$ \\
\hline $45 \%$ & $42 \%$ & $40 \%$ & $50 \%$ & High & $>35$ & $>60$ \\
\hline $\begin{array}{c}35 \%- \\
45 \%\end{array}$ & $\begin{array}{c}32 \%- \\
45 \%\end{array}$ & $\begin{array}{c}30 \%- \\
40 \%\end{array}$ & $\begin{array}{c}50 \%- \\
60 \%\end{array}$ & Marginal & $25-35$ & $50-60$ \\
\hline & & & & Low & $<25$ & $<50$ \\
\hline
\end{tabular}


Table 2.1.1 the clay soil minerals percentage of some localities using XRD.

\begin{tabular}{|l|c|c|c|c|c|}
\hline \multicolumn{5}{|c|}{ Clay Mineral \% } & \multirow{2}{*}{ Area } \\
\cline { 1 - 5 } IllitelSmectite & Chlorite & Illite & Smectite & Kaolinite & \\
\hline 10 & 5 & 2 & 70 & 3 & $\begin{array}{l}\text { Elmolaz } \\
\text { men }\end{array}$ \\
\hline 2 & 12 & 14 & 70 & 2 & $\begin{array}{l}\text { Bait } \\
\text { Elmal }\end{array}$ \\
\hline
\end{tabular}

\section{Soil stabilization by the addition of lime from Khor Eit:}

Lime $(\mathrm{CaO})$ stabilization creates a number of important engineering properties in soils, by transform the clay mineralogy in a solution the reaction called (cation exchange) or positively charged atom which are attached to the clay minerals crystal by substituting $(\mathrm{Na}+)$ by $(\mathrm{Ca}++)$ which reduced the plasticity index, reduced the expansion of the soil, and then enhanced the engineering properties (Eckel, 1928 ,and (Holtz\& Gibbs 1993) as in table 4.3).

The addition of lime yielded the lowest clay activity and plasticity index values for soil stabilization, these values became lower as soil was partially replaced with lime at 30\%, 20\% and 10\%-wt. respectively. Whoever Lim yielded an increasing of soil enhancement and stabilization at $20 \%$ and $10 \%$ the lowest values in lime percentage addition.

\section{Data modeling and of the geotechnical map generation of Omdurman:}

Data modeling involve the use of algebraic languages for manipulating the attributes tables and the spatial data .In GIS, modeling is part of the analytical process, describing, and predicting spatial phenomenon .in the current research modeling is the determination of the expansive clay, which was carried out using the class $f$ the map and the table of attributes connected to the map the polygon object highlighted in the yellow color and symbolized in the key (fig 5.1)

\section{The source of water at the studied area:}

The complied geotechnical data field and laboratory in the potential or affected area of study, other data collected during the field investigations, these data includes water resources, questionnaire collecting information from the inhabitant in the affected zone, about the main source of the water that comes from sewage system, which needs to alarm a light to the decision maker to control the distribution of the system, and to redesign them. . The expansive clay caused the cracks of the buildings as well as the main road connected Omdurman with other capital cities. 


\section{Conclusions:}

The conclusion is that to minimize the damage and risk due to the expansive clay in combination of the surface water some precaution needs to be taken.

Following solutions were suggested: Improvement of soil properties to enhance its engineering performance, the enhancement could be physically or chemically.

The chemical improvement includes addition of Lime in the percentage of $20 \%-10 \%$ ) resulting in enhancement of the soil by reducing the liquid limit.

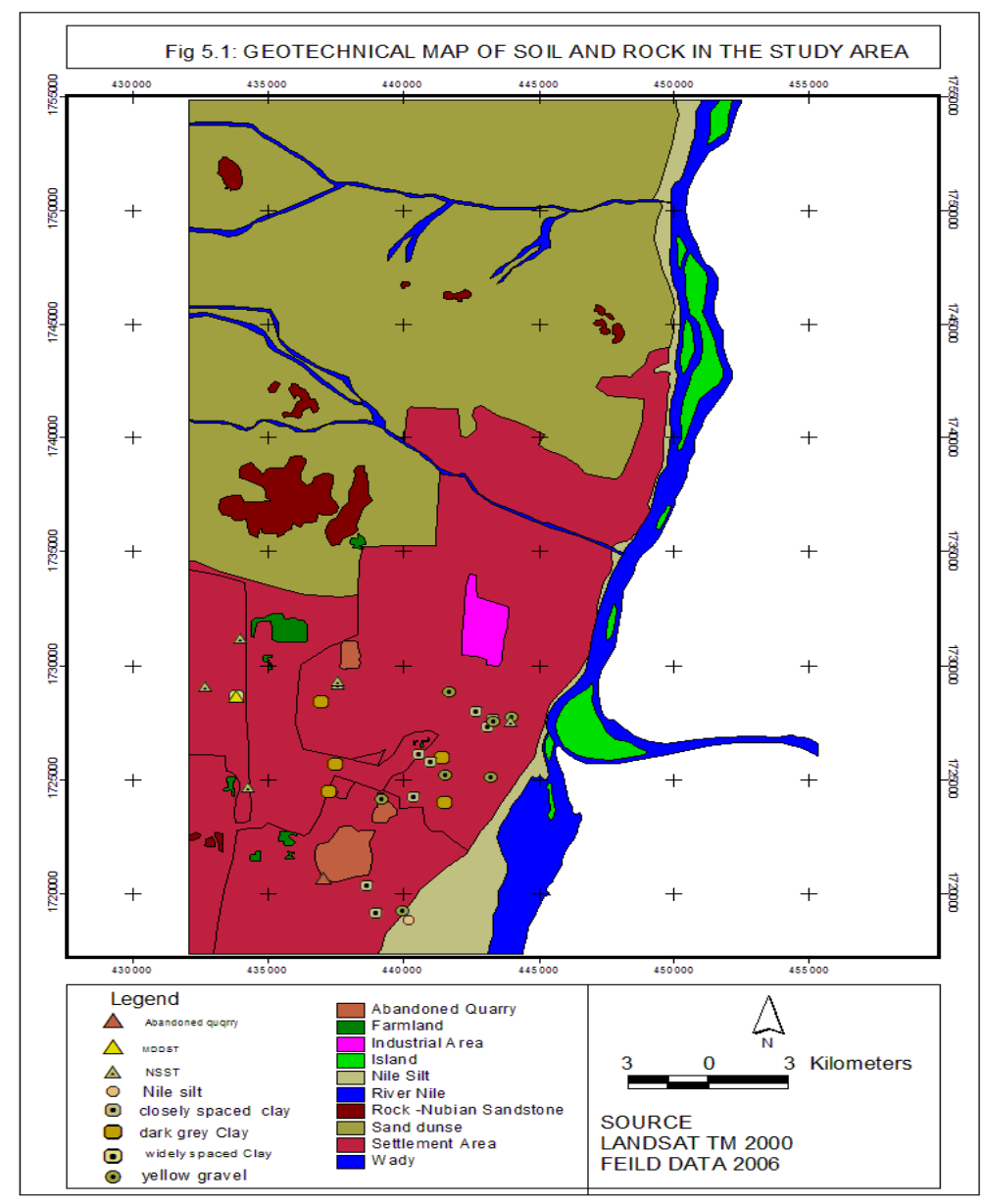

Fig (5.1)

\subsection{Recommendations:}

The recommendation as follows: Geophysical investigations should be carried out to delineate the water resources boundary to create dyke or to design drainage pattern to control the water.

Enhancements of soil could be done mechanically by static or dynamic compactions, by falling weight, vibrio wing, or vibrating plate roller.

The rapid growth of the large cities needs geotechnical information, and planning for the proper development. 


\section{Reference:}

1. Al Mond ,DC (1967),Petrology of the Basalt at Jebel Torya ,Khartoum province Sudan .

2. Ali, O.A.M.(2008), Production of Fired Clay Bricks and Pozzolana from Expansive soil, University of Khartoum, Msc thesis.

3. Boynton, R.S., 1966. Chemistry and Technology of Lime and Limestone, (John Wiley \& Sons, New York).

4. Eckel E.C., 1928. Cements, Limes and Plasters - Their Materials, Manufacture and Properties, (John Wiley \& Sons, New York), pp. 91-583.

5. Holmes S., Wingate M., 1997. Building with Lime, (Intermediate Technology Publications, London).

6. Mielenz R.C., King M.E., Physical-chemical properties and engineering performances of clays: In

Clays and Clay Technology, California Division of Mines and Geology Bulletin, 1955, 169, 196-25

7. ITC /TU Delft.

8. Internet Pages:

1. Geotextiles and Membranes ,july ,2000.An official journal of the international Geosnthetics http:// www.elsevier .ninca/publication/sore/4/0/5/8/9/7/405897.put.htt.

2. Hayward Baker - official web site geotechnical, soil ,grouting, chemical cement slurry jet compaction ,deep dynamic, ground ;http// www. Haywardbakery.com/main

3. Vibrofoation and ground improvements by vibro group,http://vibro.co.uk. 